\title{
A case of feline fibroepithelial hyperplasia in a male cat
}

\section{Case Report}

Volume: 4, Issue: 1 April 2020

Pages: 8-12

\section{Çağla Nur Küçükbekir ${ }^{1}$, Zeynep Günay Uçmak ${ }^{2 *}$, İsmail Kırşan ${ }^{2}$, Çağatay Tek ${ }^{2}$}

1. Institute of Graduate Education, University of Istanbul- Cerrahpasa, Istanbul, Turkey. 2. University of Istanbul- Cerrahpasa, Faculty of Veterinary Medicine, Department of Obstetrics and Gyneacology, Istanbul, Turkey

Küçükbekir, Ç. N.: ORCID: 0000-0002-9687-1702; Günay Uçmak, Z.: ORCID: 0000-0003-2530-1291, Kırşan I. : ORCID: 0000-0003-0780-0118, Tek, Ç.: ORCID: 0000-0002-6429-658X

\section{Article History}

Received: 20.02 .2020 Accepted: 01.04.2020 Available online: 02.04.2020

\begin{abstract}
A nine-month old, orange tabby, intact male cat was brought to our clinic with the complaint of swelling in the mammary glands. In anamnesis; long acting progesterone was administered to the cat in a private clinic for suppression of oestrus one week ago. As a result of clinical examination, fibroepithelial hyperplasia was detected in all mammary glands. For the purpose of treatment, aglepristone started to be used for sequential five days. Because ulceration and necrosis occurred in the mammary glands at the end of the first week, the treatment was completed with total mastectomy section. In this article, a case of fibroepithelial mammary hyperplasia which was formed as a result of progesterone administration to suppress the oestrus in a male cat is described.
\end{abstract}

Keywords: fibroepithelial hyperplasia, male cat, aglepristone, surgery.

DOI: 10.30704/http-www-jivs-net.691787

To cite this article: Küçükbekir, Ç. N., Günay Uçmak, Z., Kırşan, I., Tek, Ç. (2020). A case of feline fibroepithelial hyperplasia in a male cat. Journal of Istanbul Veterinary Sciences. 4(1), 8-12, Abbreviated Title: J Ist Vet Sci

\section{Introduction}

Approximately $80 \%$ of the masses in feline mammary glands are neoplastic. The benign $20 \%$ of these masses are mammary fibroadenomatosis hyperplasia, which are commonly known as fibroepithelial hyperplasia (FEH) or feline mammary hyperplasia (Görlinger et al., 2002; Allen, 1973). This condition is characterized by non-neoplastic proliferation of interlobuler ducts and periductal stromal cells (Goldschmidt et al., 2011). Fibroepithelial hyperplasia can affect all or most of the mammary glands without covering peripheral lymph nodes and it causes enlargement on several or all of the mammary glands. Meanwhile, rapid and non-neoplastic proliferation at the ductal epithelium and stroma of the mammary gland is occurred and this is usually not accompanied by milk secretion (Allen, 1973). It is known that effect of progesterone in the body or

*Corresponding Author: Zeynep Günay Uçmak

E-mail: vethekzeynep86@gmail.com externally applied synthetic progestins play role in its etiology. It is stated that this disease is occurred by the excessive response of the mammary glands to the physiological concentrations of endogenous progesterone or external progestin administration (Burstyn, 2010). Fibroepithelial hyperplasia is frequently seen in young, non-pregnant or pregnant female cats under the influence of luteal progesterone (Allen, 1973; Hayden et al., 1981; Johnston et al., 2001; Görlinger et al., 2002). This condition is generally seen in pubertas, in the first oestrus, during pregnancy or pseudopregnancy. Also it is commonly arise in young cats (13 weeks to 2 years old). Cases of fibroepithelial hyperplasia also occur in male and female cats of all ages with synthetic progestin (Hayden et al., 1981; Hayden et al., 1989; JohnsGörlinger et al., 2002, 
Mandel, 1975). This is due to the increase in the secretion of growth hormone $(\mathrm{GH})$ that produced as a side effect of the presence of ton et al., 2001; Loretti et al., 2005). However, this disease rarely arises without progesterone intake in neutered male and female cats (natural or synthetic progesterone (Mol JA et al., 1995, Mol JA et al., 1996).

Fibroepithelial hyperplasia is diagnosed as enlarged mammary glands in jelly consistency without any signs of inflammation in the initial stage. In severe cases; inflammation, tissue necrosis, ulceration, and infection may occur. The affected mammary glands of the cat with fibroepithelial hyperplasia are soft, limited and jelly-like. In addition, some patients have erythematous and necrotic areas on their skin. Anemic mucous membranes, high fever, tachycardia, apathy and anorexia can be revealed as systemic effects of the disease (Loretti et al., 2004). In the sonographic examination of the affected mammary glands, homogeneous and granular structure of parenchyma is characteristically seen. As assistant diagnostic techniques; histopathological examination of fine needle aspiration biopsy or excisional biopsy samples is also recommended (Vitasek and Dendisova, 2006; Wehrend et al., 2001).

The sexual activity of healthy male cats is manifested by intense scented urine spraying to various areas, especially when the cat is kept indoors (Dolezel et al., 2001). This behavior can be eliminated by castration. In females, progestins (eg. Medroxyprogesterone acetate, melengesterol acetate and megestrol acetate) are used in veterinary medicine to temporarily and reversibly suppress or prevent sexual activity (Romagnoli and Concannon, 2003). However, progestins applied externally in females can sometimes cause FEH in mammary glands (Hinton and Gaskell, 1977; Betlehem and van der Luer, 1993; De Souza, 2002; MacDougall, 2003; Loretti et al., 2005). In cases of feline fibroepithelial hyperplasia, regression of the enlarged mammary glands could not be possible to regress spontaneously. Treatment can only be made with the use of drugs with luteolytic effect and / or drugs to prevent endogenous progesterone effect, ovariectomy, ovariohysterectomy (Johnston et al., 2001; Keskin et al., 2008). Treatment options include total and partial mastectomy, but for medical treatment; FEH is successfully treated with the application of progesterone receptor blockers (Görlinger et al., 2002). Researchers (Görlinger et al., 2002; Nak et al., 2004; Vitasek and Dendisova, 2006; Wehrend et al.,
2001) reported that they achieved successful results by applying different treatment protocols with antigestagens.

A case of mammary gland hyperplasia which developed as a side effect of progesterone administration in order to suppress sexual activity in a male cat was presented in this article.

\section{Case}

A 9 month old, weighted $4 \mathrm{~kg}$, orange tabby male cat was presented to University Faculty of Veterinary Medicine Department of Obstetrics and Gynecology with swelling of the mammary glands. On anamnesis, it was reported that progesterone (Depo-Provera ${ }^{\circledR}$, Pfizer, Belgium) was administered for once, to suppress sexual activity. On physical examination, the cat's body temperature (rectal temperature), pulse and respiratory rate were within normal limits. On inspection, it was observed that all mammary lobes (8 lobes) of the patient were excessively swollen and the skin of the mammary was stretched (Figure 1). No inflammation, ulceration and necrosis were detected in the mammary tissue. On palpation, it was determined that the mammary glands are quite jellylike.

Complete blood count (CBC) and some biochemical parameters were evaluated in the blood samples. As a result, it was determined that reticulocyte-hemoglobin value was low $(12.5 \mathrm{pg})$ and all other parameters were within normal ranges. However, levels of serum progesterone and serum testosterone were detected within normal ranges as $0.3 \mathrm{ng} / \mathrm{ml}$ and $25 \mathrm{ng} / \mathrm{dl}$, respectively. In the ultrasonographic examination, 8 enlarged mammary lobes were visualized as encapsulated (3.3mm thick), with smooth border, hypoechogenic, and approximately $2.4 \times 4 \mathrm{~cm}$ in diameter (Figure $2 \mathrm{~A}-2 \mathrm{~B}$ ). Color doppler ultrasonography revealed peripheral and weak vascularization in the enlarged mammary tissues (Figure 2B).

Based on the anamnesis and typical clinical findings, the patient was diagnosed with fibroepithelial mammary hyperplasia. Since there was no necrosis and ulceration in the hyperplastic mammary glands, medical therapy was applied firstly. For this purpose; Aglepristone (Alizine, Virbac ${ }^{\circledR}$, France) was administered once daily for 5 days at a dose of $15 \mathrm{mg} \mathrm{/} \mathrm{kg.} \mathrm{Aglepristone} \mathrm{has} \mathrm{special}$ administration way. It is applied subcutaneous way at the inner side of back leg to avoid the local alopecia and deposition of the drug into the adipose tissue. 


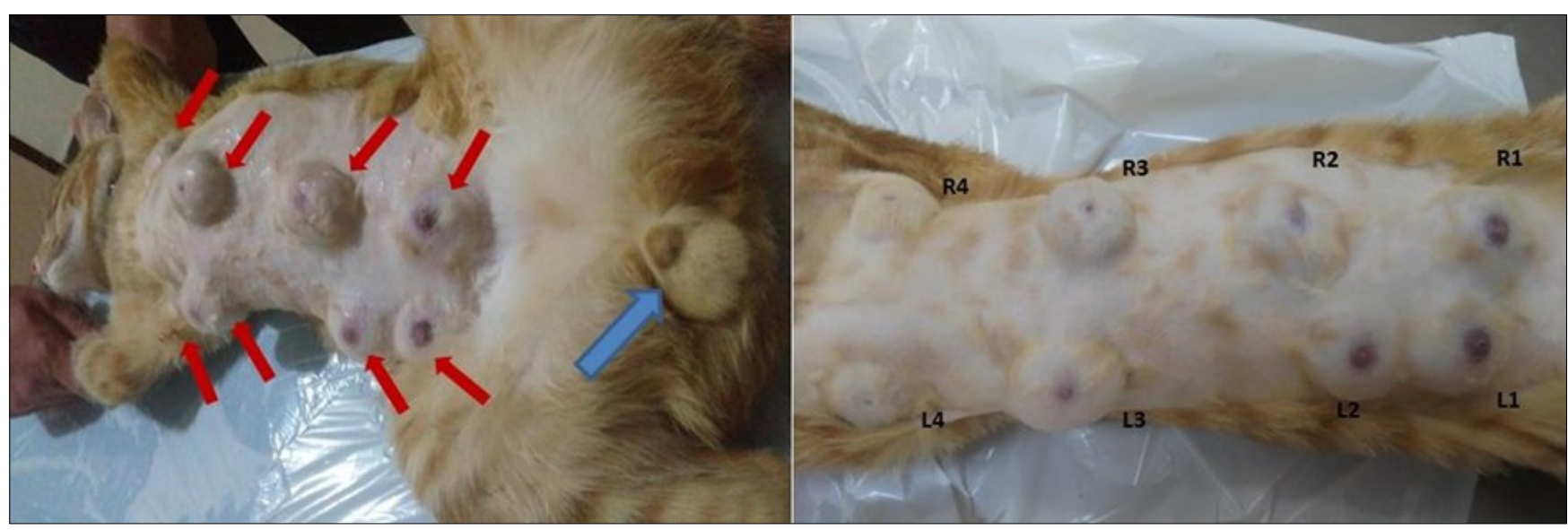

Figure 1. Enlarged mammary glands in a male cat. Red arrows: Enlarged mammary lobes, Blue arrow: Gonads of male cat. R: Right chain of mammary glands, L: Left chain of mammary glands.

Chondroitin polysulfide containing topical cream cold compresses were applied daily (Hirudoid, Santa Farma, Turkey) to the region. During the treatment, no side effects such as tachycardia and hair loss were observed. According to the control examination performed at the end of one week, there was no regression in the mammary glands and ulceration started. Therefore, the treatment was continued surgically and total mastectomy was performed to the cat. Atropine sulfate $(0.03 \mathrm{mg} / \mathrm{kg}$ subcutaneously (sc); Atropin ${ }^{\circledR}$, Teknovet, Turkey) was administrated for premedication. After induction with $1 \%$ propofol (4 $\mathrm{mg} / \mathrm{kg}$, intravenously (iv); Lipuro ${ }^{\circledR}$, Braun, UK), general anesthesia was continued with isoflurane (\% 3) (Forane Liquid $^{\circledR}$, Abbott Laboratories, UK) and oxygen (\% 0.5 - \% 1). Because the male cat was less than a year old (9 month), castration was not performed during the total mastectomy operation. No complications occurred after total mastectomy. After the operation, isotonic $0.9 \%$ sodium chloride (Isotonic Eczacibasi, Turkey) was administered once daily at a dose of $10 \mathrm{ml} / \mathrm{kg}$ for three days. Also the cat was treated with amoxicillin clavulanic acid (sid, $20 \mathrm{mg} / \mathrm{kg}$, sc; Synulox ${ }^{\circledast}$, Pfizer, USA), enrofloxacin $5 \%$ (sid, $5 \mathrm{mg}$ / $\mathrm{kg}$, sc; Baytril- $\mathrm{K}^{\circledR}$ 5\%, Bayer, Turkey), vitamin B12 (40 $\mathrm{mg} / \mathrm{kg}$, im, sid; Dodex ${ }^{\circledR}$, Deva, Turkey) and ranitidine (sid, $1 \mathrm{mg} / \mathrm{kg}$, im; Ulcuran ${ }^{\circledR}$, Yavuz Drug, Turkey) for a week. Skin sutures were removed on the fifteenth day after the operation.

\section{Discussion}

Fibroepithelial hyperplasia is defined as enlargement of one or all mammary glands without milk production (Bethlehem and Van der I., 1993). It has also been reported that FEH in female cats can be seen during pseudopregnancy and usually occurs under the influence of endogenous progesterone (Görlinger et al., 2002). However, in neutered or sexually intact
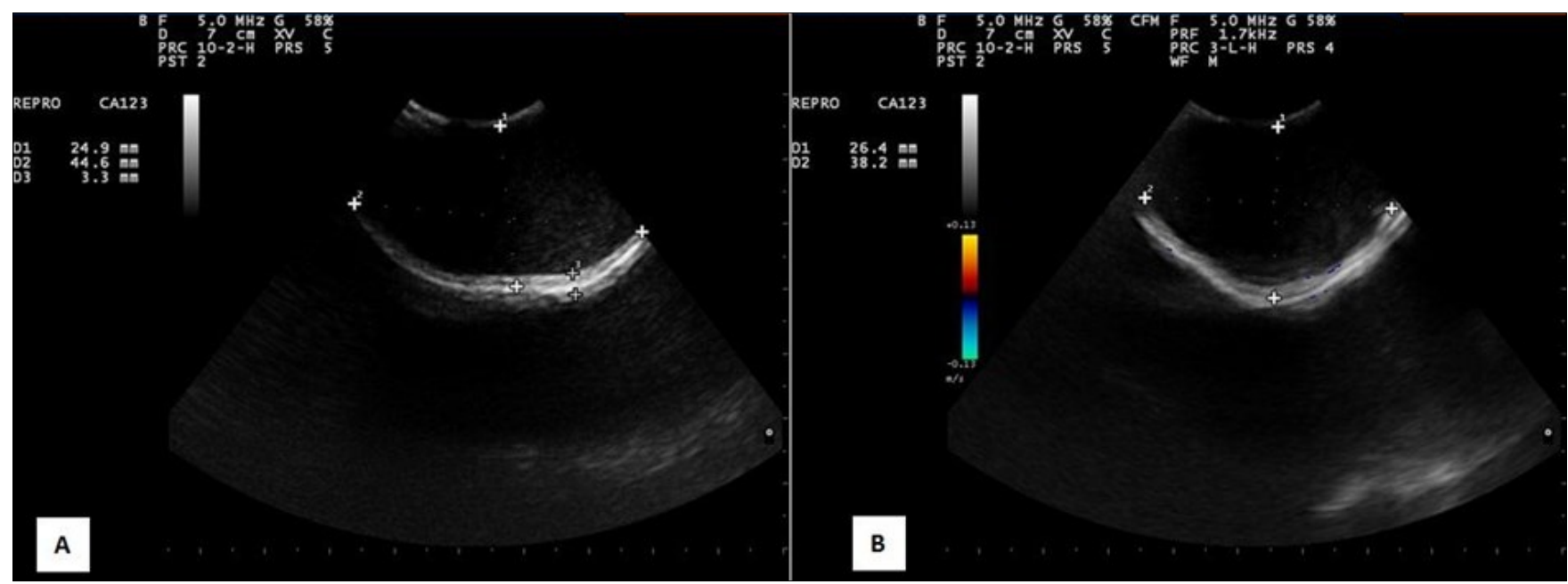

Figure 2. A: B-mod ultrasonography image and measurement of enlarged mammary lobe. B: Color doppler images and measurement of enlarged mammary lobe 
female cats, FEH can occur by external administration of progesterone containing compounds (Medroxyprogesterone acetate or megestrol acetate) (Nak et al., 2004; Uçmak et al., 2011). In line with the previous reports (Nak et al., 2004; Uçmak et al., 2011), FEH was shaped immediately after long acting (3 months) progesterone administration detected $\mathrm{FEH}$ in 1 castrated and 2 non-castrated male cats (Görlinger et al., 2002). Similar to Görlinger et al. (2002), FEH was detected in non-castrated male cat. The researchers (Nak et al., 2004; Wehrend et al., 2001) reported that aglepristone is administered subcutaneously at a dose of $10 \mathrm{mg} / \mathrm{kg}$ for 5 times in 21 days (1-2-7-14-21th days) for the treatment of feline FEH. On the other hand Uçmak et al. (2011) achieved successful results in the treatment of FEH by using subcutaneous administration of aglepristone at the dose of $15 \mathrm{mg} / \mathrm{kg}$ for 5 consecutive days. In accordance with the researchers' report (Uçmak et al., 2011), aglepristone was administered at the dose of $15 \mathrm{mg} /$ $\mathrm{kg}$ subcutaneously from the inside of the back legs

\section{References}

Allen, H. L. (1973). Feline mammary hypertrophy. Veterinary Pathology, 10, 501-508.

Baştan, A., Fındık, M., Erünal, N., Aslan, S., \& Kılıçoğlu, Ç. (1998). The use of cabergoline for the treatment of pseudopregnancy in dogs with the purpose of suppressing lactation. Reproduction in Domestic Animal, 33, 49-53.

Bethlehem, M., \& Van Der Luer, R. J. (1993). Feline fibroepithelial hyperplasia in 3 castrated tomcats following treatment with progestagens. Tijdschrift Voor Diergeneeskunde, 15, 650-652.

Burstyn, U. (2010). Management of mastitis and abscessation of mammary glands secondary to fibroadenomatous hyperplasia in a primiparturient cat. Journal of the American Veterinary Medical Association, 236, 326-329.

Chisholm, H. (1993). Massive mammary enlargement in a cat. Canadian Veterinary Journal, 34, 315.

De Souza, T. M., Fighere, R. A., Langohr, I. M., \& De Bartos, C. S. L. (2002). Hiperplasia fibroepithelial mamaria em felinos: Cinco casos. Ciencia Rural, 32, 891-894.

Dolezel, R., Vitasek, R., \& Senior, D. F. (2001). Hayden, D. W., Barnes, D. M., \& Johnson, K. H. Disturbances of reproductive system. Small Animal (1989). Morphologic changes in the mammary gland for 5 consecutive days for the treatment of FEH in the presented case. Görlinger et al. (2002) reported that they also treated FEH in male cats using progesterone receptor blockers. In contrast to Görlinger et al. (2002), treatment with aglepristone could not be continued for more than a week due to ulceration and necrosis in the mammary glands. Similar with Chisholm (1993), mastectomy was performed as an appropriate treatment option in

(Piyarungsri et al., 2020) reported a high risk of lower urinary tract disease (FLUTD) in male cats due to the castration performed before one year of age. In line with the previous report, castration was not performed during the surgical intervention, because the male cat was 9 months old in this case.

In conclusion, FEH could develop in mammary glands of male cats as a result of progesterone administration to with urine. Additionally; it has been concluded that surgical intervention should be considered as an altsuppress the sexual activity and its symptoms such as marking ernative treatment option in cases which do not respond to medication.

Veterinary Association, 1253-1357.

Goldschmidt, M., Pena, L., Rasotto. R., \& Zappulli, V. (2011). Classification and grading of canine mammary tumors. Veterinary Pathology, 48, 117131.

Görlinger, S., Kooistra, H. S., Van Den Broek, A., \& Okkens, A. C. (2002). Treatment of fibroadenomatous hyperplasia in cats with aglepristone. Journal of Veterinary Internal Medicine, 16, 710- 713.

Gültiken, N., Aslan, S., Ay, S. S., Gülbahar, M. Y., Thuróczy, J., Koldaş, E., Kaya, D, Fındık, M., \& Schäfer Somi, S. (2017). Effect of deslorelin on testicular function, serum dihydrotestosterone and oestradiol concentrations during and after suppression of sexual activity in tom cats. Journal of Feline Medicine and Surgery, 19(2), 123-131.

Hayden, D. W., Johnston, S. D., Kiang, D. T., Johnson, K. H., \& Barnes, D. M. (1981). Feline mammary hypertrophy fibroadenoma complex: clinical and hormonal aspects. American Journal of Veterinary Research, 42, 1699-1703. 
of megestrol acetatetreated and untreated cats: a Mol, J. A., Van Garderen, E., Rutteman, G. R., \& retrospective study. Veterinary Pathology, 26, 104113.

Hinton, M., \& Gaskell, C. J. (1977). Non-neoplastic mammary hypertrophy in the cat associated ether with pregnancy or with oral progestagen therapy. Veterinary Record, 100, 277-280.

Jelinek, F., Barton, R., Posekana, J., \& Hasonova, L. (2007). Gynaecomastia in a tom-cat caused by cyproterone acetate: a case report. Veterinarni Medicina, 52(11), 521-525.

Johnston, S. D., Kustritz, M. V. R., \& Olson, P. N. S. (2001). Mammary hypertropy. Canine and feline theriogenology. Philadelphia, PA: Saunders.

Keskin, A., Yılmazbaş, G., Şimşek, G., \& İntaş, K. S. (2008). Mammary hyperplasia in a pregnant queen. Australian Veterinary Practitoner, 38, 75.

Loretti, A. P., Ilha, M. R. S., Breitsameter, I., \& Faraca, C. S. (2004). Clinical and pathological study of feline mammary fibroadenomatous change associated with depot medroxyprogesterone acetate therapy. Arquivo Brasilero de Medicina Veterinariae Zootecnia, 56(2), 270-274.

Loretti, A. P., Ilha, M. R., Ordas, J., \& Martin de las Mulas, J. (2005). Clinical, pathological and immunohistochemical study of feline mammary fibroepithelial hyperplasia following a single injection of depot medroxyprogesterone acetate. Journal of Feline Medicine Surgery, 7, 43-52.

MacDougall, L. D. (2003). Mammary fibroadenomatous hyperplasia in a young cat attributed to treatment with megestrol acetate. Canadian Veterinary Journal, 44, 227-229.

Mandel, M. (1975). Spontaneous remission of feline benign mammary hypertrophy. Veterinary Medicine Small Animal Clinician, 70, 846-847.

Mayayol, S. L., Bo, S., \& Pisu, M. C. (2018). Mammary fibroadenomatous hyperplasia in a male cat. Journal of Feline Medicine and Surgery Open Reports. 1-5.

Mol, J. A., Henzen-Logmans, S. C., Hageman, P., Misdorp, W., Blankenstein, M. A., \& Rijnberk, A. (1995). Expression of the gene encoding growth hormone in the human mammary gland. The Journal of Clinical Endocrinology and Metabolism, 80, 3094Rijnberk, A. (1996). New insights in the molecular mechanism of progestin-induced proliferation of mammary epithelium: induction of the local biosynthesis of growth hormone (GH) in the mammary glands of dogs, cats and humans. The Journal of Steroid Biochemistry and Molecular Biology, 57, 67-71.

Nak, D., Nak, Y., İntaş, K. S., \& Kumru, i. H. (2004). Treatment of feline mammary fibroadenomatous hyperplasia with aglepristone. Australian Veterinary Practitoner, 34(4), 161-162.

Özenç, E., \& Bozkurt, M. F. (2014). Atypical fibroepithelial hyperplasia of the teats in a Sphynx cat: a case report. Veterinární medicína,59(5), 265269.

Piyarungsri, K., Tangtrongsup, S., Thitaram, N., Lekklar, P., \& Kittinuntasilp, A. (2020). Prevalence and risk factors of feline lower urinary tract. Scientific Reports, 10, 196.

Romagnoli, S., \& Concannon, P. W. (2003). Clinical use of progestins in bitches and queens: a review. Recent Advances in Small Animal Reproduction. International Veterinary Information Service Ithaca, A1206.0903.

Uçmak, M., Enginler, S. Ö., Gündüz, M. C., Kırşan, İ., \& Sönmez, K. (2011). Treatment of feline mammary fibroepithelial hyperplasia with the combination of aglepristone and cabergoline. Journal of the Faculty of Veterinary Medicine, Istanbul University, 37(1), 6973.

Verstegen, J. P. (1998). Pharmacological control of reproduction in the cat. Manuel of small animal reproduction and neonatology, 219-226.

Vitasek, R, \& Dendisova, H. (2006). Treatment of feline fibroepithelial hyperplasia following a single injection of proligestone. Acta Veterinaria Brno, 75, 295-297.

Wehrend, A., Hospes, R., \& Gruber, A.D. (2001). Treatment of feline fibroadenomatous hyperplasia with a progesterone antagonist. Veterinary Record, 148, 346-347.

Zertova, H. (2001). Disorders of behaviour in dogs and cats. Czech Small Animal Veterinary Association, 1645-1679. 